

\title{
Pedagogic discourse: Marshalling register variation $^{1}$
}

\section{El discurso pedagógico: El dominio de la variación de registro}

\author{
James Martin \\ UNIVERSITY OF SYDNEY \\ AUSTRALIA \\ james.martin@sydney.edu.au
}

\author{
Recibido: 21-VII-2021 / Aceptado: 08-XI-2021 \\ DOI: $10.4067 /$ S0718-09342021000300771
}

\begin{abstract}
In this paper, I approach the question of what makes a text coherent from a pedagogic perspective. I begin with Halliday and Hasan's (1976) canonical observation that a coherent text must be 'consistent in register'. I then explore this notion from the perspective of a stratified model of context (as genre and register), focusing on a law lecture text dealing with misrepresentation. Shifts in field, mode and tenor are documented for this text, challenging the idea that a coherent text must in some sense be the 'same' register throughout. I then bridge from recent work in Legitimation Code Theory (its autonomy plane) to propose a revised SFL model of pedagogic discourse. This is used to re-interpret register shifting in the law lecture as shifting in the service of its curriculum genre. I close with discussion of the implications of these observations for modelling context and for respecting lecturing mode as far as its complementary role in teaching/learning is concerned.
\end{abstract}

Key Words: Pedagogic discourse, register variation, autonomy, language and the law, field shifting, lecturing.

\section{Resumen}

En este artículo abordo la cuestión de qué hace que un texto sea coherente desde una perspectiva pedagógica. Comienzo con la observación canónica de Halliday y Hasan (1976) de que un texto coherente debe ser 'consistente en el registro'. A continuación, exploro esta noción desde la perspectiva de un modelo estratificado de contexto (como género y registro), centrándome en un texto de una clase de derecho que trata de la entrega de información que resulta ser falsa. En este texto se documentan los cambios de campo, de modo y de tenor, lo que pone en tela de juicio la idea de que un texto coherente debe tener, en cierto sentido, el 'mismo' registro en todo momento. Luego, hago un puente a partir del trabajo reciente en la Teoría de Códigos de Legitimación (su plano de autonomía) para proponer un modelo revisado de discurso pedagógico en la 
LSF. Esto se utiliza para reinterpretar el cambio de registro en la clase de derecho como un cambio al servicio de su género curricular. Concluyo con la discusión de las implicaciones de estas observaciones para modelar el contexto y para respetar el modo de clase expositiva en relación a su papel complementario en la enseñanza/aprendizaje.

Palabras Clave: Discurso pedagógico, variación de registro, autonomía, lenguaje y derecho, cambio de campo, clase expositiva.

\section{INTRODUCTION}

In 2003, Giovanni Parodi invited me to give a series of lectures on discourse analysis at the Graduate School of Linguistics of the Pontificia Universidad Católica de Valparaíso (Chile) - attended by local research students and colleagues and in addition by a small group from the Universidad Nacional de Cuyo in Mendoza (Argentina). Later that year, Giovanni spent several weeks as a visiting scholar at the University of Sydney, further developing our collaboration; and in 2004, the 'Mendocina' who attended my lectures organised the first Latin American SFL conference, with the theme 'Systemic Functional Linguistics in Language Education'. This was the beginning of a rich, engaging and ongoing process of collaboration involving dozens of research students and colleagues from Australia and Latin America - all seeded by Giovanni's vision of socially responsible linguistic research which is designed to make a contribution to the world. We shared in particular a concern with discourse analysis in relation to language education. Accordingly, I have chosen to offer a paper from this field as part of this special issue of Revista Signos. Estudios de Lingüistica, which I am honoured to dedicate to my deeply missed colleague and very dear friend.

\section{Coherence and cohesion}

In simple terms, phonologists worry about what makes a word pronounceable; grammarians worry about what makes sentence utterable; and discourse analysts worry about what makes a text apprehensible. From the perspective of Systemic Functional Linguistics (hereafter SFL) what makes a text a text is that it is:

"is a passage of discourse which is coherent in these two regards: it is coherent with respect to the context of situation, and therefore consistent in register; and it is coherent with respect to itself, and therefore cohesive" (Halliday \& Hasan, 1976: 23).

In this paper I will explore what it means to argue that a text is "consistent in register", focusing on a passage of pedagogic discourse - specifically part of a law lecture introduced in Hood and Maggiora (2016: 112) and used with their permission.

The model of SFL I am assuming here features a stratified model of context (as genre and register; Martin, 1992; Martin \& Rose, 2008) and a stratified model of language (as discourse semantics, lexicogrammar and phonology; Halliday (1985) and subsequent editions, Martin, 1992; Martin \& Rose, 2007; Halliday \& Greaves, 2008). 
Moving down from the highest level of abstraction, we have genre realized by register patterns, register realised by discourse semantic patterns, discourse semantics realized by lexicogrammatical patterns and lexicogrammar realized by phonological patterns. This kind of realisational patterning is referred to as metaredundancy (Halliday, 1991; Lemke, 1995; Taverniers, 2019), with more abstract levels supervenient on less abstract ones (Martin, Wang \& Zhu, 2013). As annotated in Figure 1, in this particular SFL model we have both a stratified context plane (i.e. genre realised through register) and a stratified content plane (discourse semantics realised through lexicogrammar).

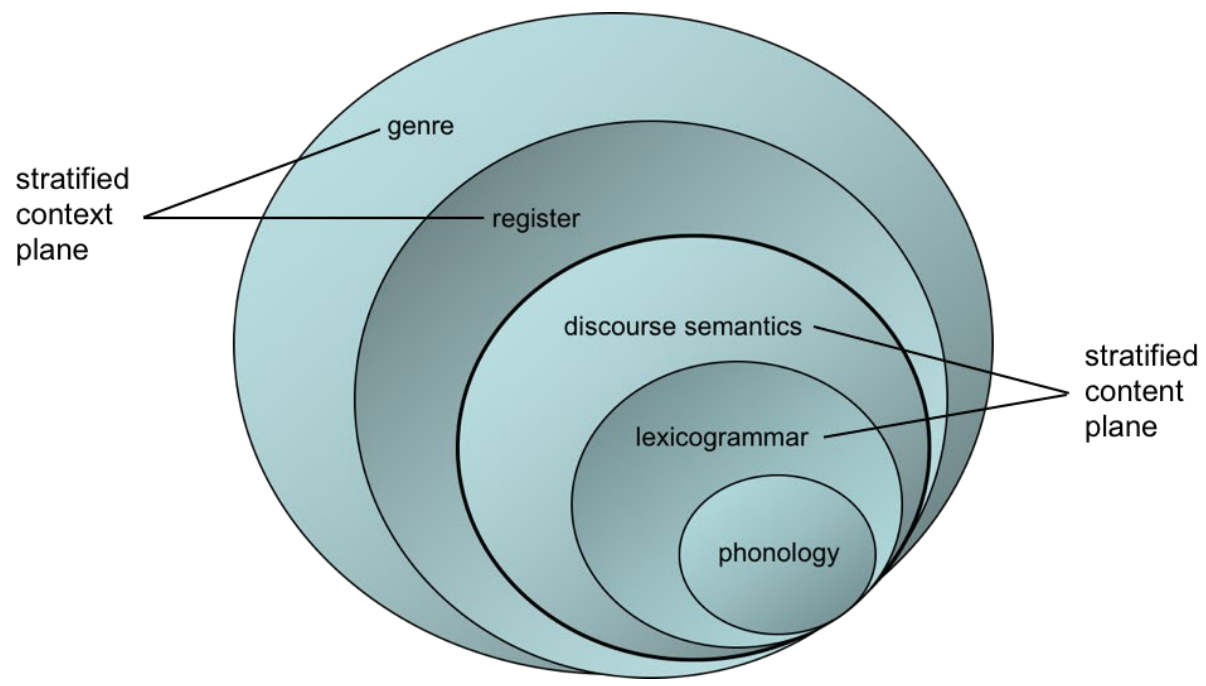

Figure 1. A stratified model of language and context.

As imaged in Figure 1, the stratified model of language and context assumed here treats context as higher level social semiosis (realised through patterns of linguistic patterns). Alongside stratification, the model I am assuming involves a metafunctional perspective on semiosis -with interpersonal resources enacting social relations (i.e. tenor), ideational resources construing activity (i.e. field) and textual resources composing information flow (according to the mode). So the intrinsic functionality of language (the interpersonal, ideational and textual metafunctions) is correlated with the extrinsic functionality of context (the register variables tenor, field and mode respectively). This trinocular perspective on social semiosis is outlined in Figure 2. For discussion of the development of this particular model of SFL see Martin (2014, 2016). 


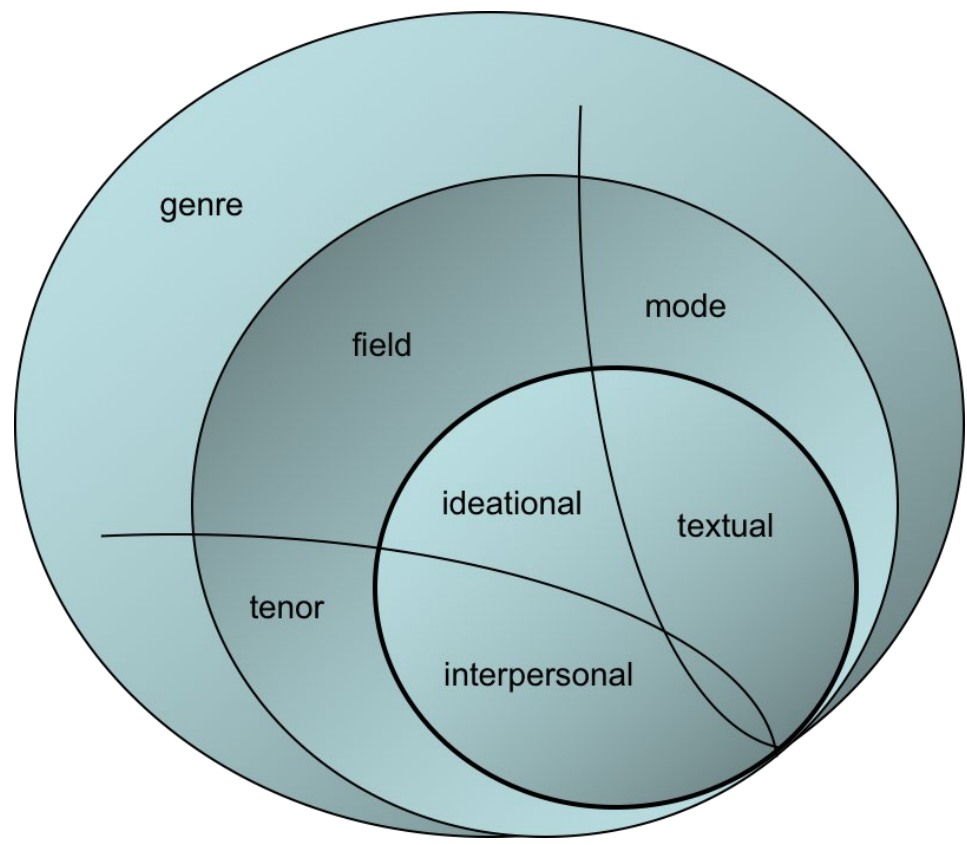

Figure 2. Correlation of language metafunctions and register variables.

We are now positioned to clarify our approach to a discussion of 'consistent in register' for purposes of this paper. Our focus will be on the register variables field, tenor and mode. We begin with a consideration of field, looking at what we might informally think of as topic shifts within our law lecture. We then build a model accommodating these shifts - drawing on ongoing dialogue between SFL and Legitimation Code Theory (Christie \& Martin, 2007; Christie \& Maton, 2011; Martin, 2020a; Maton, Martin \& Doran, 2021). As a final step we review some of the pedagogical implications of register variation, bringing shifts in mode and tenor into the picture. As we will see, a model of curriculum genres (Rose \& Martin, 2012; Rose, 2020) which is sensitive to register shifting is essential if we are to make any sense of what we mean by evaluating a teaching text as coherent - not in spite of, but because of, changes in register.

\section{Teaching law}

The focus text for this paper is set out below - in stages and phases (following Martin \& Rose, 2008; Martin, 2020a). Basically we are dealing with a story genre (an exemplum in particular), which deals with a passenger who missed his flight because it was overbooked and his subsequent legal battle with the airline. As we can see as its Interpretation stage unfolds (as background, dispute, judgement, clarification), it is not told simply to make a point about how exasperating airlines can be, but beyond this to make a point about the legal concept of misrepresentation (in layperson's terms, lying to customers). The text is taken from a first year university lecture on tort law. 


\section{[1] Abstract}

So... British Airways and Taylor.

\section{Orientation}

Taylor was a guy who worked for a consumer agency, a government agency. He was representing a guy called Edmonds. Edmonds had lived on the island of Bermuda for a long time, down there in the Caribbean. Liked that sunshine.

\section{Incident}

Decided after many years of this he'd like to take a holiday in London. Experience some of that fog and dampness. Get up there. Take in some shows. Go to Wimbledon. Hadn't had a holiday for a long, long time and so this is a big deal for him. Cheap airfare was on offer if you were the early bird. Get in a couple of months early, you book your name, much cheaper. So he did this. Books his flight for London. Plans his holidays. Becomes a little bit concerned that maybe his place will get taken if there's a crowd, and someone who paid full fare would be in his seat. So he rings them up gets some reassurance that that's not the case. There will be a seat for him. And in fact gets a letter confirming the seat that's there. Obviously he turns up at the airport in Bermuda, no seat.

\section{Interpretation}

[background] It turns out that the policy of British Airways, along with many of its competitors, was to overbook because it was realised that some people don't turn up, they get sick, there's misadventure. So you always overbook and that way you don't have vacant seats and you are able to maximise the income of the flight.

[dispute] Didn't work this time. Only two times, the facts indicated, in every 10,000 bookings does someone not make it. But the airline had said to him ${ }^{\circ}$ There is a seat for you.' They did not reveal this idea that in very extreme circumstances there may not be a seat. Didn't reveal that. So British Airways' argument was 'Well this is so remote. It is so unlikely to occur that we don't worry about it and you really can't class it as a misrepresentation, a deceit'. Of course Edmonds had the other view. 'Been waiting for years for my holiday. Wanted to get up to London. Now I can't get there. Everything's mucked up.' So you see the logic of both arguments.

[judgement] Well the courts tend to take a dim view of anyone who lies irrespective of the reasons, at least in commerce anyway. And Lord Wilberforce said this. 'The letter, taken with the ticket, would be taken as a statement that Mr. Edmonds had a certain booking, which statement, in view of the overbooking policy, was untrue, since his booking, though very likely to be a firm one, was exposed to risk, small, but as events proved real, and it might give him a seat on the aircraft, it might not. This was a statement of fact rather than a statement of mere intention.' 
[clarification] Hence, this was considered then a statement of fact. Why? Because you told me today there was a seat for me in the future. It was not really, as you've masked it, a statement today that you intend to give me a seat in the future. Do you see the subtle difference? Not sure? Too subtle? Not getting a lot of feedback here. Is anyone unsure of the subtlety, the difference between someone...? Remember the example we used the other day when we were talking about this sort of stuff. If someone says to you, 'Will you meet me for coffee tomorrow, at ten o'clock?'and you say 'Yes.' and at the time you say that you have no intention of turning up, even though it is in the future, it is still a lie today. Correct? This is the same thing in this case. Yep... '[some question-answer discussion follows]'

From the perspective of field, in text (1) there is more than one thing going on realised through the different phases of the Interpretation. We have (i) Edmond's aborted holiday, (ii) the legal discourse comprising Lord Wilberforce's judgement, (iii) the pedagogic discourse apprenticing the law students, (iv) a reference to masks and (v) meeting up for coffee. Plenty of topic shifting; but the lecturer is not rambling incoherently. What is going on?

\section{Field}

In section 2, we suggested, from a common-sense point of view, that our law lecture text involves several fields. This begs the question of course of what we mean by field. Let's explore this more precisely here, focusing on the legal discourse the law lecturer is teaching for purposes of illustration. Following Doran and Martin (2021) field is conceived as a resource for construing phenomena -'dynamically' as activities oriented to some global institutional purpose, or 'statically' as items involved in these activities (taxonomised with respect to both classification and composition), along with associated properties.

Beginning with the static perspective, classification in tort law is illustrated in Figure 3 (taken from the law lecturer's data projection). Therein the legal item misrepresentation is subclassified as fraudulent, negligent or innocent. 




Figure 3. Types of misrepresentation.

Composition in tort law is illustrated in Figure 4 (again taken from the law lecturer's projection). Therein the legal item misrepresentation is positioned as comprising 5 elements (as a false statement of fact between parties intended to and in fact inducing a contract)

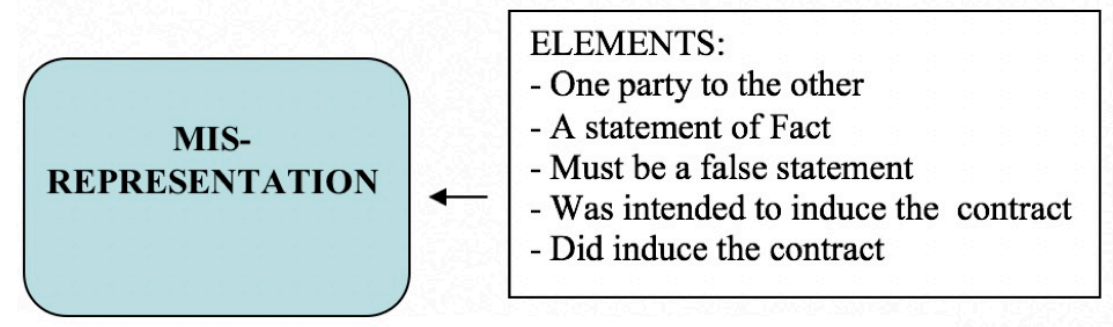

Figure 4. Elements of misrepresentation.

Turning to a dynamic perspective each type of misrepresentation potentially triggers a lawsuit. In the case of fraudulent misrepresentation, the lawsuit involves suing in the tort of deceit and rescind. This civil litigation involves a number of tiers of activity. There is the suit as a whole. And it can be broken down into 9 sequential steps (optional steps in parentheses):




Any one of these can be broken down on a third tier; the court hearing activity is expanded as 4 steps below:

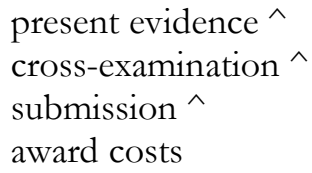

Finally, we have possibility of properties assigned to items and activity. Lord Wilburforce draws on a number of these in his judgement - 'certain', 'untrue', 'firm', 'risk', 'small', 'real' and 'mere'.

So taking tort law as an example, and focusing on misrepresentation, we can see that field involves a set of activities oriented to some specific institutional purpose, alongside items involved in these activities (organised by both classification and composition) and any associated properties. And field shift involves moving from one of these 'activity plus item plus property' complexes of meaning to another. So when we say that text 1 involves 5 fields - (i) Edmond's aborted holiday, (ii) the legal discourse comprising Lord Wilberforce's judgement, (iii) the pedagogic discourse apprenticing the law students, (iv) a reference to masks and (v) meeting up for coffee - we are saying that activities, the classification and composition of items involved and/or associated properties in some sense change. An outline of the very general systems involved is presented as Figure 5.

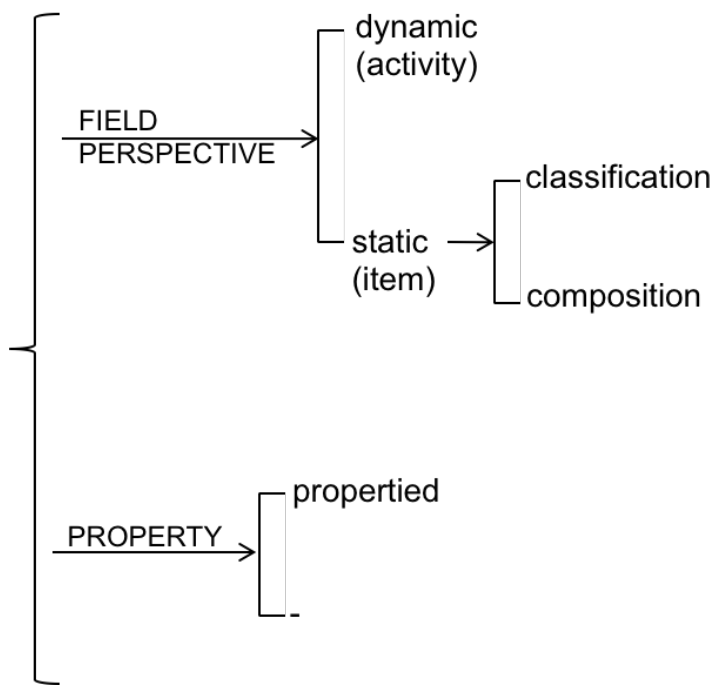

Figure 5. Field resources.

So, why does field shift? Let's begin with the least developed field - masking. This is brought in as the 'source' of a traditional lexical metaphor; its 'target' is the airline's argument that the ticket they issued and follow-up letter simply stated their intention to give Edmonds a seat in the future, not that he was guaranteed one. As with all lexical metaphors (Martin \& White, 2005; Martin, 2020b) the motivation for bringing the two 
fields together, with one symbolising the other, is attitudinal. The lecturer's suggestion here is that the airline was deliberately disguising the nature of their offer - a negative judgment of its behaviour.

[2] Hence, this was considered then a statement of fact. Why? Because you told me today there was a seat for me in the future. It was not really, as you've masked it, a statement today that you intend to give me a seat in the future.

Two fields are also brought together in relation to meeting up for coffee. But in this case the motivation is to explain by analogy (rather than to draw on one field to evaluate another). A parallel is drawn between promising to have coffee with someone without intending to and issuing an airline ticket without guaranteeing a seat. This brings what the lecturer characterises as a subtle legal distinction down to earth - to demonstrate that it is indeed possible to lie about the future.

[3] Remember the example we used the other day when we were talking about this sort of stuff. If someone says to you, "Will you meet me for coffee tomorrow, at ten o'clock?" and you say "Yes." and at the time you say that you have no intention of turning up, even though it is in the future, it is still a lie today. Correct? 'This is the same thing in this case.

The aborted holiday field of course comes in as the incident the legal case is arbitrating. The specialised field of law has evolved to deal with matters obtaining in other fields - it adjudicates a world outside itself (just as a specialised field like linguistics evolves its metalanguage to explain the language phenomena it selects as its object of inquiry).

[4] Decided after many years of this he'd like to take a holiday in London. Experience some of that fog and dampness. Get up there. Take in some shows. Go to Wimbledon. Hadn't had a holiday for a long, long time and so this is a big deal for him. Cheap airfare was on offer if you were the early bird. Get in a couple of months early, you book your name, much cheaper. So he did this. Books his flight for London. Plans his holidays. Becomes a little bit concerned that maybe his place will get taken if there's a crowd, and someone who paid full fare would be in his seat. So he rings them up gets some reassurance that that's not the case. There will be a seat for him. And in fact gets a letter confirming the seat that's there. Obviously he turns up at the airport in Bermuda, no seat.

The specialised field of law, which students are being apprenticed into, is most clearly articulated in Lord Wilberforce's judgement. We are dealing here with common law, not civil law, and so precedents are fundamental. Knowing what counts legally as a statement of fact (as opposed to a statement of intention) and being able to refer to canonical cases is crucial.

[5] "The letter, taken with the ticket, would be taken as a statement that Mr. Edmonds had a certain booking, which statement, in view of the overbooking policy, was untrue, since his booking, though very likely to be a firm one, was 
exposed to risk, small, but as events proved real, and it might give him a seat on the aircraft, it might not. This was a statement of fact rather than a statement of mere intention."

Finally, we have what is in some respects the most 'implicit' of the fields in this discourse - the actual teaching itself. I say 'implicit', because ideational resources are not deployed to talk about what is going on. Rather we are looking a teaching as practice. Below in Figure 6 I highlight one of the key discourse semantic patterns drawing our attention to this practice - namely the use of internal connexion (Martin, 1992; Hao, 2020) to scaffold phases of the lecturer's presentation. I have also highlighted one instance involving text reference and a semiotic entity ('the other view'), which relates the two sides of the legal disputation to one another. These resources are deployed to scaffold the teaching of the law (not the structure of the legal concepts in play).

$\Uparrow \mathrm{So}_{\mathrm{O}} \Rightarrow$ British Airways and Taylor. Taylor was a guy who worked for a consumer agency, a government agency. He was representing a guy called Edmonds. ...

$\Uparrow \mathrm{So} \Rightarrow$ British Airways' argument was "Well this is so remote. It is so unlikely to occur that we don't worry about it and you really can't class it as a misrepresentation, a deceit". ...

$\Uparrow$

Of course Edmonds had the other view. "Been waiting for years for my holidays. Wanted to get up to London. Now I can't get there. Everything's mucked up.”

$\Uparrow$ So you see the logic of both arguments.

$\Uparrow \mathrm{Well} \Rightarrow$ the courts tend to take a dim view of anyone who lies irrespective of the reasons, at least in commerce anyway. ...

$\Uparrow$ Hence, $\Rightarrow$ this was considered then a statement of fact. ...

Figure 6. Internal connexion scaffolding the lecture.

As we can see, the main reason our text might be viewed as 'inconsistent' in register is that it is a teaching text - in Bernstein's terms (1996) it is an instance of pedagogic discourse. Field shifts are brought in to explain the law. This challenges SFL to develop a model of context that effectively models teaching practice, a challenge to which we now turn.

\section{Modelling pedagogic discourse}

Work on pedagogic discourse in SFL is inspired by Bernstein's theorising of the sociology of education. Bernstein (1996: 46-50) defines pedagogic discourse as follows:

"I will define pedagogic discourse as a rule which embeds two discourses; a discourse of skills of various kinds and their relations to each other (= instructional discourse; JRM), and a discourse of social order (= regulative discourse; JRM)... the instructional discourse is embedded in the regulative discourse... to create one text... one discourse... the regulative discourse is 
the dominant discourse... produces the order in the instructional discourse... the purpose of the device is to produce a symbolic ruler for consciousness..."

The idea of two discourses and one text of course resonates with SFL's distinction between realisation (the levels of abstraction introduced above) and instantiation (the process whereby systemic potential is actualised in unfolding discourse). From the perspective of realisation a text is many things, and can be described from the perspective any stratum or metafunction; but from the perspective of instantiation a text is one thing - a seamlessly integrated tapestry of meanings drawn together from across strata and metafunctions (and any other dimensions our realisation hierarchy takes into account).

Bernstein's suggestion that regulative discourse is the dominant discourse, in which instructional discourse is embedded, is more challenging to 'translate' into SFL - since terminologically speaking embedding has a technical meaning in SFL having to do with a unit of the same or higher rank realising a specific function (rather than a unit of the rank below playing this role). Martin (1999a, 1999b) and Christie (2002) were inspired by Bernstein's distinction to refer to a regulative register projecting an instructional one - adopting the SFL term projection for the relationship between the two registers. As Christie explains (2002: 25), this term better suggests that some field is "taken, relocated and in some sense therefore 'projected' for another purpose and another site". Reasoning along these lines, our law lecture configures two fields - an educational register which projects a legal one.

Extending this formulation, Rose (2020) models curriculum genres as configuring two registers, a curriculum register (comprising knowledge and values) that is exchanged between teachers and learners through a pedagogic register (comprising pedagogic relations, pedagogic activities and pedagogic modalities). These are specific patterns of tenor, field and mode instantiated in curriculum genres. This model of curriculum genres is schematised as Figure 7. Research applying this model has been largely concerned with analysis and design of pedagogic registers (Humphrey, Hao \& Rose, 2020). Here we are particularly concerned with multiple fields in a curriculum register. This schema makes room for a more nuanced account of the relation between the education field and the knowledge and values it is projecting, including addressing the challenge of modelling projections involving additional shifts in field, such as those canvassed above. 


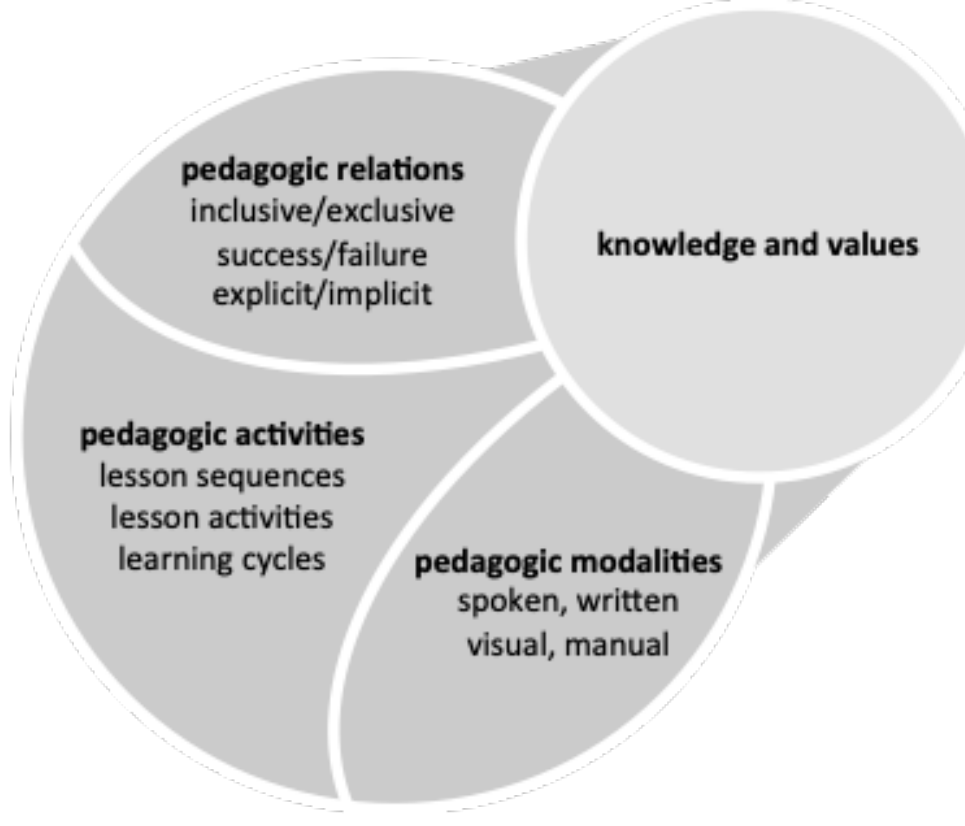

Figure 7. Rose's SFL model of pedagogic discourse (curriculum genres).

To pursue this challenge, we turn to work on recent work on autonomy codes in Legitimation Code Theory (hereafter LCT). In Maton and Howard's (2018: 6) terms, this dimension of LCT is introduced as follows (their actual layout has been adjusted below): "Autonomy begins from the simple premise that any set of practices comprises constituents that are related together in particular ways ..."

Constituents may be actors, ideas, artefacts, institutions, machine elements, body movements, sounds, etc.; how such constituents are related together may be based on explicit procedures, tacit conventions, mechanisms, explicitly stated aims, unstated orthodoxies, formal rules, etc.

Autonomy codes explore the boundaries that practices establish around their constituents and the boundaries they establish around how those constituents are related together.

- positional autonomy (PA) between constituents positioned within a context or category and those positioned in other contexts or categories; and

- relational autonomy (RA) between relations among constituents of a context or category and relations among constituents of other contexts or categories.

They continue by noting that both positional and relational autonomy can be stronger or weaker according to the degree of insulation between categories. 
"Stronger positional autonomy $(\mathrm{PA}+)$ indicates where constituents positioned in a context or category are relatively strongly delimited from constituents attributed to other contexts or categories, and weaker positional autonomy (PA-) indicates where such distinctions are drawn relatively weakly.

Stronger relational autonomy $(\mathrm{RA}+)$ indicates where the principles governing how constituents are related together are relatively specific to that set of practices, i.e. purposes, aims, ways of working, etc. are autonomous; and weaker relational autonomy (RA-) indicates where the principles governing how constituents are related together may be drawn from or shared with other sets of practices, i.e. purposes, aims, ways of working, etc. are heteronomous."

These strengths are visualised as the 'autonomy plane' presented as Figure 8, which highlights four 'autonomy codes', given by varying the strengths of PA and RA. The key issue for enacting these ideas is the notion of 'target' (Maton \& Howard, 2021). Put simply, researchers ask: what is the target content (giving PA+) and what is the target purpose (giving RA+) of the practices being analysed? Once we know the target, then we can locate practices on the plane and see how they change through time.

Let's take as an example me teaching linguistics. My target content is linguistic theory or description and my target purpose is teaching that linguistic theory or description. So, when I'm discussing linguistic theory I am inside my target content $(\mathrm{PA}+)$ and when I'm discussing something else I am outside that target content (PA-); and when I'm using whatever I'm discussing to teach linguistic theory I am inside my target purpose $(\mathrm{RA}+)$ and when I'm using whatever I'm discussing for something else I am outside my target purpose (RA-).

So, when I use the familiar SFL railway metaphor of shunting (switching) to talk about reasoning from above, below and around with reference to a category, I am drawing on non-target content (a railway analogy) for a target purpose (to explain linguistic) - this is an introjected code (see Figure 8). Were I to use linguistic analysis to explain something in the science fiction film 'Arrival', based on the short story by Chiang (1998), I'd be discussing target content (linguistic theory) for non-target purposes (informing the field of entertainment). If I digress, perhaps to bond (successfully or not) with students in terms of recent sporting events (ice hockey, cricket, tennis etc.) I'd be discussing non-target content for non-target purposes - an exotic code. My moves from one code to another are referred to in LCT as 'autonomy pathways' of various kinds. We can translate these ideas to the linguistic analysis of pedagogic discourse to create an attractive, theoretically informed way of thinking about the field shifting and consistency in register issue framing this paper. 


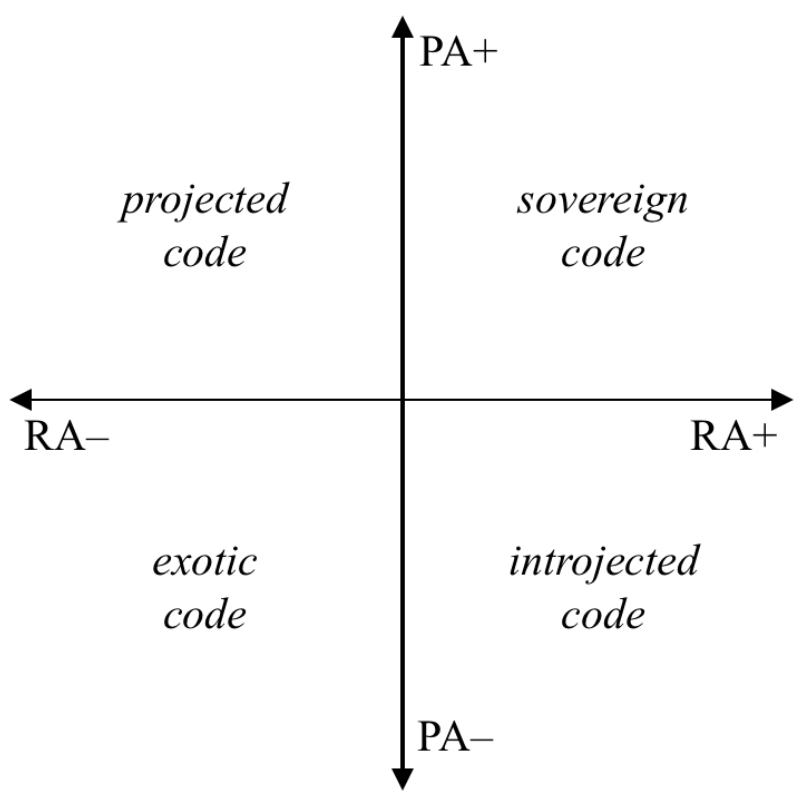

Figure 8. LCT's autonomy plane.

Dialogue between SFL and LCT has been one of the most productive highlights of my academic career over the past two decades (Christie \& Martin, 2007; Christie \& Maton, 2011; Martin, Maton \& Doran, 2020a; Maton et al., 2021). One thing we have learned from working together on data in relation to problems we share is that is it essential to be clear about the complementarity of our respective theoretical and descriptive frameworks (Martin, 2011; Martin, Maton \& Doran, 2020b) and not mix categories as we inspire and provoke one another. Accordingly, I am going to suggest an SFL topology here, which will allow us to think about field shifting in pedagogic discourse in terms germane to SFL. This topology in effect translates LCT's abstract concepts (which could be applied to various objects of study) into a more specific tool (focusing on the linguistic analysis of pedagogic discourse).

As reviewed above, from the perspective of SFL one of the distinctive features of pedagogic discourse is that it involves two fields - in simple terms the field of education projecting the field being taught (physics, history, mathematic etc.). I'll refer to the projected field as disciplinary discourse (DD), and set up a vertical axis along which phases of discourse can be interpreted as construing the knowledge and values of a disciplinary field to a greater or lesser degree (from +DD to -DD).

The reason we have two fields in pedagogic discourse is that one or another curriculum genre is organising the teaching/learning. These curriculum genres involve recurrent configurations of field, mode and tenor (Rose's pedagogic relations, pedagogic activities and pedagogic modalities) - distinguishing one teaching/learning practice from another. And these recurrent configurations of educational variables are organised 
to apprentice students into another field (its activities, items, properties and its values). I'll refer to these projecting curriculum genres as educational discourse (ED) and set up a horizontal axis along which phases of discourse can be interpreted as more or less under the control of the curriculum genre (from +ED to -ED). The resulting topology is outlined in Figure 9.

+DD (subject field)



-DD (other field)

Figure 9. Pedagogic discourse - an SFL perspective.

As annotated in Figure 9, when a curriculum genre is projecting a disciplinary field we have dedicated discourse $(+\mathrm{ED},+\mathrm{DD})$; when the curriculum genre marshals a nondisciplinary field to explain a disciplinary one we have dialogic discourse (+ED, -DD); when the curriculum genre gives way to another genre which itself draws on a disciplinary field in some way we have deployed discourse $(-\mathrm{ED},+\mathrm{DD})$; and when the curriculum genre gives way to another genre and another field we have divergent discourse (-ED, -DD). With dialogic discourse we are in a sense importing the activities, items and/or properties of a field in support of a curriculum genre. With deployed discourse on the other hand we are in a sense exporting the activities, items and/or properties of a disciplinary field in support of another social activity (i.e. an other than curriculum genre).

If we replay the examples introduced above to illustrate autonomy codes from LCT, then discussing linguistic theory or description for purposes of apprenticing students would be dedicated discourse, using the railway shunting metaphor for comparable apprenticeship would be dialogic discourse, using linguistics to inform a science fiction film or short story would be deployed discourse and celebrating or bemoaning a sporting event would be divergent discourse.

As far as our law lecture is concerned, we have two dedicated discourses and three dialogic ones. The legal field (i.e. misrepresentation) and the pedagogic activity (i.e. the 
teaching/learning going on) are dedicated discourses - the former projected by the latter. ${ }^{2}$ The events of Edmond's aborted holiday, the mask metaphor and the coffee date analogy are dialogic discourses - marshalled by the curriculum genre to i) instance the case on which Lord Wilburforce's judgement bears, ii) make a negative judgement of the airline's behaviour and iii) relate the subtle distinction between a statement of fact and an intention to everyday experience. The presence of five fields makes perfect sense given the pedagogic focus of the lecture genre. Text [1]'s coherence does not depend on registerial consistency; it depends rather on purposing shifts to the needs of its curriculum genre.

\section{Lecturing}

To this point in the paper we have focused primarily on register variation in relation to field. But our law lecture exhibits shifts in mode and tenor as well. In general terms, these shifts, like the field shifts discussed above, are in the service of the curriculum genre and its teaching/learning mission. This raises an important issue having to do with the role of lecturing in education and how we appreciate its affordances and limitations (Hood \& Lander, 2016; Hood \& Maggiora, 2016; Hood, 2020).

To further explore register variation within a text let's look in more detail at what Rose (2020) refers to as pedagogic activity. As outlined in Figure 10, Rose models teaching/learning as a series of learning cycles, each with a nuclear task. In effective pedagogy students are adequately prepared to succeed and supported where necessary by a move focusing their attention; tasks are of course evaluated (positively since students have been primed for success) and elaborated (by way of reinforcing or extending the learnings to hand).

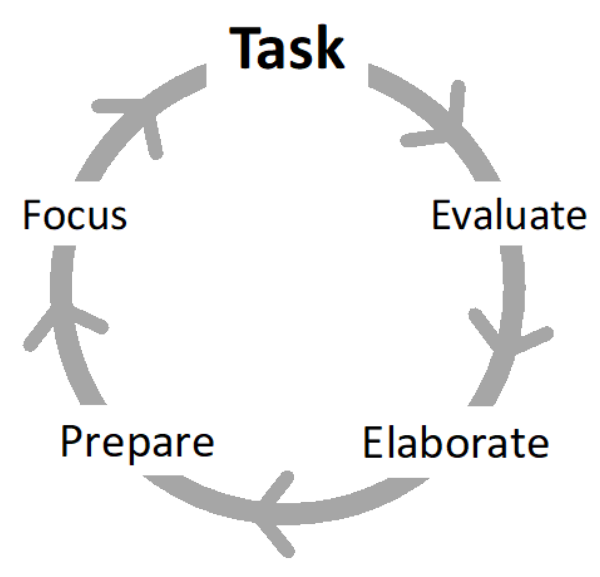

Figure 10. Phases of pedagogic activity. 
Teaching/learning models of this kind are usually introduced in relation to interactive phases of pedagogic discourse. For example, earlier on in our law lecturer, there is a review of what is meant by rescission. By way of preparation the lecturer situates students in the broader field - with respect to the activities which result in a rescission and the types and elements of misrepresentation that require one (Figures 3 and Figure 4 above). He then focuses their attention on the task to hand - defining rescission. One student successfully completes this task and is positively evaluated for their move; the lecturer then goes on to elaborate on the different types of tort leading to rescission, with or without damages.

Table 1. Rose's teaching/learning cycle illustrated.

\begin{tabular}{|l|l|l|}
\hline speaker & activity & discourse \\
\hline Lecturer & Prepare & $\begin{array}{l}\text { So we look at all these particular things, we go through all our elements; } \\
\text { each element must be there to constitute a misrepresentation and to bring } \\
\text { about a rescission. }\end{array}$ \\
\hline Student & Focus & What was a rescission? Anyone recall? \\
\hline Lecturer & Evaluate & - Returning parties to the position they were in beforehand. \\
\cline { 2 - 3 } & Elaborate & $\begin{array}{l}\text { - Yes, good. } \\
\text { for goods, you get your money back, the proprietor gets his/her goods } \\
\text { back. So that is the solution, on a contractual level. If someone has lied } \\
\text { to you, deceived you, deliberately, then you also have a remedy in the tort } \\
\text { of deceit. You're not allowed to lie to people, and if there is damages } \\
\text { associated with that, the victim will be awarded those damages. If } \\
\text { someone has been negligent in the statement they make to you, causing } \\
\text { you to enter into a contract, then to lose, money in particular, you'll have } \\
\text { a suit in the tort of negligence. If it is an innocent misrepresentation, in } \\
\text { other words, it's neither negligent nor fraudulent, rescission of contract } \\
\text { but no damages, no tort of innocence. }\end{array}$ \\
\hline
\end{tabular}

But in lecture mode interactive phases of this kind tend to be intermittent punctuating longer stretches of discourse without turn-taking. The students' task during these 'monologic' phases is that of attending to knowledge (Rose, 2018). But we need to be careful here. Calling these phases monologic does not mean that there is no pedagogic activity going on. Teaching/learning is underway, in a mode that has evolved over millennia to introduce students to specialised fields - in contexts where students need to be provided with an orientation to the written texts where the specialised knowledge is stored. In these modes the teaching/learning is not enacted through dialogic interaction. Rather it is realised through shifts in register - including the field shifts reviewed above. Let's look at a few of these from text [1].

The most obvious field shifts, when we are dealing with a specialised field, are shifts in technicality. In text [3] above for example, repeated as [3'] below, the lecturer uses an analogy to render the technical legal term 'misrepresentation' as the everyday common sense term 'lie'. 
[3'] Remember the example we used the other day when we were talking about this sort of stuff. If someone says to you, "Will you meet me for coffee tomorrow, at ten o'clock?" and you say "Yes." and at the time you say that you have no intention of turning up, even though it is in the future, it is still a lie today. Correct? This is the same thing in this case.

As with all 'translations', the meaning shifts. The idea that you can lie about the future is not common sense. And care must be taken not to move the students from uncommon into common sense and strand them there (Martin, 2013). But as part of a process of moving between more and less technical construals of knowledge, field shifting of this kind is a valuable part of teaching practice.

Let's look now at a dimension of field shifting that is a little less obvious. This has to do with the tendency in legal discourse to reason within clause complexes rather than between them (cf. Martin \& Rose, 2007 on legislation). ${ }^{3}$ Lord Wilburforce's judgement is a case in point, drawing as it does on a full range of expansion resources to establish his precedent. Its complexity is such that we will introduce the reasoning in stages. His overall argument is that the airline's letter to Edmonds would be taken as a statement that he had a seat, which was untrue because his booking was exposed to risk. This is outlined below following Halliday (1985 and subsequent editions). ${ }^{4}$

\begin{tabular}{|l|l|l}
\hline$\alpha$ & & $\begin{array}{l}\text { The letter }<<\ldots>>\text { would be taken as a statement [[that Mr. } \\
\text { Edmonds had a certain booking]], }\end{array}$ \\
\hline$=\beta$ & $\alpha$ & which statem ent, in view of the overbooking policy, was untrue, \\
\hline & $\mathbf{x} \beta$ & since his booking $<<\ldots>>$ was exposed to risk, \\
\hline
\end{tabular}

He supports the idea that the booking was exposed to risk by clarifying that it might or might not provide him with a seat.

\begin{tabular}{|l|l|l|l|l|}
\hline$\alpha$ & & & & $\begin{array}{l}\text { The letter }<<. .>>\text { would be taken as a statement [Ithat Mr. Edmonds had a } \\
\text { certain bookingll, }\end{array}$ \\
\hline$=\beta$ & $\alpha$ & & & which statement, in view of the overbooking policy, was untrue, \\
\hline & $\mathbf{x} \beta$ & 1 & & since his booking $<<. .>>$ was exposed to nisk, \\
\hline & & +2 & 1 & and it might give him a seat on the aircraft, \\
\hline & & & +2 & it might not. \\
\hline
\end{tabular}

This is elaborated by accepting the airline's argument that the risk was small (just twice in every 10,000 bookings) but countering that the risk was real. 


\begin{tabular}{|c|c|c|c|c|c|}
\hline $\boldsymbol{\alpha}$ & & & & & $\begin{array}{l}\text { The letter }<<\ldots>>\text { would be taken as a statement [[that Mr. } \\
\text { Edmonds had a certain booking]], }\end{array}$ \\
\hline \multirow[t]{6}{*}{$=\beta$} & $\boldsymbol{\alpha}$ & & & & which statement, in view of the overbooking policy, was untrue, \\
\hline & $\mathbf{x \beta}$ & 1 & $\boldsymbol{\alpha}$ & & since his booking $\langle<\ldots>>$ was exposed to risk, \\
\hline & & & $=\beta$ & 1 & small \\
\hline & & & & +2 & but $\ll<\ldots>$ real, \\
\hline & & +2 & 1 & & and it might give him a seat on the aircraft, \\
\hline & & & +2 & & it might not. \\
\hline
\end{tabular}

This leaves us with three included clauses to take into account. This first clarifies that it was not just the letter, but in addition the ticket, which would be taken as a statement. The second deals further with the idea of risk, allowing that the booking was very likely to be firm. And the third confirms that Edmonds having missed his flight proves risk was real.

\begin{tabular}{|c|c|c|c|c|c|c|}
\hline \multirow[t]{2}{*}{$\alpha$} & $\alpha$ & & & & & $\begin{array}{l}\text { The letter }<<\ldots>\text { would be taken as a statement } \\
\text { [[that Mr. Edmonds had a certain booking]], }\end{array}$ \\
\hline & $\ll \beta \beta>$ & & & & & $<<$,taken with the ticket $>>$ \\
\hline \multirow[t]{8}{*}{$=\beta$} & $\boldsymbol{\alpha}$ & & & & & $\begin{array}{l}\text { which statement, in view of the overbooking } \\
\text { policy, was untrue, }\end{array}$ \\
\hline & $\mathbf{x \beta}$ & 1 & $\boldsymbol{\alpha}$ & $\boldsymbol{\alpha}$ & & since his booking $<<\ldots .>>$ was exposed to risk \\
\hline & & & & $<<x \beta>$ & & $<<$, though very likely to be a firm one, $>>$ \\
\hline & & & $=\beta$ & 1 & & small \\
\hline & & & & +2 & $\boldsymbol{\alpha}$ & but $<<\ldots>>$ real, \\
\hline & & & & & $\ll x \beta \gg\rangle$ & $<<$ as events proved $>>$ \\
\hline & & +2 & 1 & & & and it might give him a seat on the aircraft, \\
\hline & & & +2 & & & it might not. \\
\hline
\end{tabular}

The arguments of British Airways and Taylor (Edmonds' lawyer) can thus be seen to shape this discourse - giving rise to the complexity of Wilburforce's finely tuned multiclause adjudication.

By way of explaining this judgement the lecturer tones down the complexity considerably. Where Wilburforce used one clause complex, the lecturer uses 13 (annotated by roman numerals below). Nine of these are simplexes (I, II, V, VI, II, VIII, IX, XII, XIII), consisting of just a single ranking clause. ${ }^{5}$ And the first three complexes consist of just two ranking clauses (III, IV and X). It is only in clause complex XI that the lecturer stretches out, using 7 ranking clauses to develop his coffee date analogy - a complex that is arguably easier to follow than Wilburforce's judgement because i) it deals with everyday experience, ii) includes two direct quotations, iii) has just one interrupting clause (not several) and iv) is shorter. 


\begin{tabular}{|c|c|c|c|c|}
\hline I & & & & Hence, this was considered then a statement of fact. /// \\
\hline II & & & & Why? /// \\
\hline \multirow[t]{2}{*}{ III } & $\alpha$ & & & Because you told me today // \\
\hline & $" \beta$ & & & there was a seat for me in the future. /// \\
\hline \multirow[t]{2}{*}{ IV } & $\alpha$ & & & $\begin{array}{l}\text { It was not really }<<\ldots>>\text { a statement today [[that you intend to give } \\
\text { me a seat in the future]]. /// }\end{array}$ \\
\hline & $<<x \beta>>$ & & & $<<$, as you've masked it, $>>$ \\
\hline $\mathrm{V}$ & & & & Do you see the subtle difference? /// \\
\hline VI & & & & Not sure? /// \\
\hline VII & & & & Too subtle? /// \\
\hline VIII & & & & Not getting a lot of feedback here. /// \\
\hline IX & & & & $\begin{array}{l}\text { Is anyone unsure of the subtlety, the difference between someone...? } \\
/ / /\end{array}$ \\
\hline \multirow[t]{2}{*}{$\mathrm{X}$} & $\alpha$ & & & Remember the example we used the other day // \\
\hline & $x \beta$ & & & when we were talking about this sort of stuff. /// \\
\hline \multirow[t]{7}{*}{$\mathrm{XI}$} & $x \beta$ & 1 & 1 & If someone says to you // \\
\hline & & & "2 & , "Will you meet me for coffee tomorrow, at ten o'clock?" // \\
\hline & & +2 & 1 & and you say // \\
\hline & & & "2 & "Yes." // \\
\hline & & +3 & & $\begin{array}{l}\text { and at the time [[you say that]] you have no intention of turning up } \\
/ /\end{array}$ \\
\hline & $\alpha$ & $x \beta$ & & , even though it is in the future // \\
\hline & & $\alpha$ & & , it is still a lie today. /// \\
\hline XII & & & & Correct? /// \\
\hline XIII & & & & This is the same thing in this case. /// \\
\hline
\end{tabular}

At the same time, although only the lecturer is speaking, this phase is far more interactive than say Wilburforce's judgment or the chronicling of Edmond's aborted holiday and ensuing suit. The lecturer addresses 7 questions to his students:

Why?

Do you see the subtle difference?

Not sure?

Too subtle?

Is anyone unsure of the subtlety, the difference between someone...?

Remember the example we used the other day when we were talking about this sort of stuff?

Correct?

And there are two exchanges, with the lecturer himself providing both the initiation and response:

Why?

- Because you told me today there was a seat for me in the future.

"Will you meet me for coffee tomorrow, at ten o'clock?"

and you say "Yes."

And some further interaction (not included in text [1]), with turn-taking by both the lecturer and students, ensues. 
The general point here is that just because one person is speaking we should not assume that a text is not engaging with students (Hood \& Zhang, 2020). The lecturer is addressing his students, whether they take a turn at speaking or not - just as he is clearly taking them into account by adjusting his technicality and breaking Wilburforce's reasoning down into digestible chunks.

We've now looked at ideational shifts (technicality and reasoning) in relation to field and interpersonal shifts (questions and turn-taking) in relation to tenor. As a final step we'll look at textual shifts in the pattern of information flow and their impact on how 'spoken' the discourse sounds (i.e. its mode). A analysis of information flow in ranking clauses is provided in Table 2 (following the strategies outlined in Martin \& Rose, 2007). As we can see, the unmarked Themes are strongly oriented to Edmonds; and these Themes are in fact implicit 11 out of 15 times (as marked by parentheses in the table). This texture earmarks the discourse as informal spoken mode - positioning the lecturer as a casual raconteur, entertaining his audience.

Table 2. Information flow in the Incident.

\begin{tabular}{|c|c|c|c|}
\hline Linker & Comment & Unmarked Theme & Minimal New6 \\
\hline & & (he) $[=$ Edmonds $]$ & after many years of this \\
\hline & & he & a holiday in London. \\
\hline & & (he) $[=$ Edmonds $]$ & some of that fog and dampness. \\
\hline & & (he) [=Edmonds] & up there [=London]. \\
\hline & & (he) $[=$ Edmonds $]$ & some shows. \\
\hline & & (he) $[=$ Edmonds] & to Wimbleton. \\
\hline & & (he) $[=$ Edmonds $]$ & for a long, long time \\
\hline \multirow[t]{2}{*}{ and so } & & this $[=$ holiday $]$ & a big deal for him. \\
\hline & & cheap airfare & on offer \\
\hline \multirow[t]{4}{*}{ if } & & you & the early bird. \\
\hline & & (you) & a couple of months early \\
\hline & & you & your name \\
\hline & & (it) [= airfare] & much cheaper. \\
\hline \multirow[t]{4}{*}{ So } & & he $[=$ Edmonds $]$ & this $[=$ book early]. \\
\hline & & (he) $[=$ Edmonds] & his flight for London. \\
\hline & & (he) $[=$ Edmonds $]$ & his holidays. \\
\hline & & (he) $[=$ Edmonds $]$ & $\begin{array}{l}\text { a little bit concerned [[that maybe his place will get } \\
\text { taken]] }\end{array}$ \\
\hline if & & there & a crowd \\
\hline and & & $\begin{array}{l}\text { someone who } \\
\text { paid... }\end{array}$ & in his seat. \\
\hline \multirow[t]{3}{*}{ So } & & he $[=$ Edmonds $]$ & rings...up \\
\hline & & (he) $[=$ Edmonds $]$ & $\begin{array}{l}\text { some reassurance that that }[=\text { seat taken }] \text { 's not the } \\
\text { case. }\end{array}$ \\
\hline & & There & a seat for him. \\
\hline \multirow[t]{3}{*}{$\begin{array}{l}\text { And in } \\
\text { fact }\end{array}$} & & (he) $[=$ Edmonds $]$ & a letter confirming the seat that's there. \\
\hline & obviously & he $[=$ Edmonds] & at the airport in Bermuda \\
\hline & & (there) & no seat. \\
\hline
\end{tabular}


Subsequently, in his Interpretation of the Incident, the lecturer changes gears, reverting to his customary less informal mode to explain why Edmonds lost his seat. Information flow in the first two phases of the Interpretation is presented in Table 3. Here the unmarked Themes compose a much wider orientation to the field - including reference to British Airline's policy, their clients in general, the airline, their argument, Lord Wilberforce and Edmonds. And there are only 4 implicit Themes. The lecturer has his teaching hat on again - he orients his students' attention to more items than Edmonds and does so relatively explicitly.

Table 3. Information flow in the first two phases of the Interpretation.

\begin{tabular}{|c|c|c|c|c|}
\hline Linker & Comment $^{7}$ & $\begin{array}{l}\text { Marked } \\
\text { theme }\end{array}$ & $\begin{array}{l}\text { Unmarked } \\
\text { theme }\end{array}$ & Minimal new \\
\hline & It turns out & & the policy of BA & to overbook \\
\hline \multirow[t]{3}{*}{ because } & it was realised & & some people & turn up, \\
\hline & & & they $[=$ people $]$ & sick, \\
\hline & & & There & misadventure. \\
\hline \multirow[t]{2}{*}{ So } & & & you & overbook \\
\hline & & That way & you & vacant seats \\
\hline \multirow[t]{3}{*}{ and } & & & you & the income of the flight. \\
\hline & & & (it) $[=$ policy $]$ & this time, \\
\hline & $\begin{array}{ll}\text { the facts } \\
\text { indicated }\end{array}$ & $\begin{array}{l}\text { Only } \quad \text { two } \\
\text { times... }\end{array}$ & someone & not make it. \\
\hline \multirow[t]{4}{*}{ But } & & & the airline & to him \\
\hline & & & "There & for you." \\
\hline & & & They [=airline $]$ & $\begin{array}{l}\text { this idea that...there may not be } \\
\text { a seat }\end{array}$ \\
\hline & & & (they) $[=$ airline $]$ & that $[=$ not be a seat $]$ \\
\hline So & & & BA's argument & "well this is so remote... a deceit" \\
\hline \multirow[t]{2}{*}{ Well } & & & this [= not be a seat $]$ & so remote \\
\hline & & & It $[=$ not be a seat $]$ & so unlikely to occur \\
\hline that & & & $\begin{array}{ll}\text { we } & {[\text { British }} \\
\text { Airways }] & \end{array}$ & about it [= not be a seat $]$ \\
\hline \multirow[t]{6}{*}{ and } & & & you $[=$ Wilberforce $]$ & as a misrepresentation, a deceit \\
\hline & Of course & & Edmonds & the other view: "...mucked up" \\
\hline & & & (I) $[=E d m o n d s]$ & for my holiday \\
\hline & & & (I) $[=$ Edmonds $]$ & to London \\
\hline & & Now & $\mathrm{I}[=E d m o n d s]$ & there [to London] \\
\hline & & & Everything & mucked up \\
\hline So & & & you [=students] & the logic of both arguments \\
\hline
\end{tabular}

There are obviously many more dimensions of meaning which we could pursue to explore how the lecturer changes gears, adjusting the field, tenor and mode of his presentation as he apprentices law students into the uncommon sense he needs them to understand. Some shifts are more dramatic than others - i.e. the field shifts from legal to everyday discourses through which we opened this discussion. But others are smaller, and arguably operating within a field - the difference between Lord Wilburforce's and the lecturer's clause complexing for example. This argues for a topological model such as that proposed in Figure 9, which allows us to model degrees 
of shift along continua, rather than having to categorise changes as moves from one category to another.

The main pedagogic point we need to take from this section is that effective teaching/learning necessarily involves movement with respect to field and with respect to tenor and with respect to mode. This happens whether the teaching/learning involves turn-taking or not. So a 'monologic' lecture, with only intermittent turn-taking, can be as engaging, student-centred and 'interactive' as a face-to-face tutorial with plenty of repartee. There is nothing in the mode to stop the same kind of shifting going on. As analysts we have to address the meanings in play and push beyond a shallow focus on the channel of communication and the turn-taking it facilitates or affords. Only then can we appreciate and think about how to evaluate the effectiveness of teaching/learning as we move from one sector of education and one discipline to another.

\section{Implications for theory and practice}

We began this paper by querying what exactly is meant by the phrase 'consistent in register' in SFL - one of the two key measures of coherence proposed by Halliday and Hasan (1976). Clearly, as illustrated by text [1], coherent texts do shift gears. Their field, their tenor and their mode are not identical throughout. So 'consistent in register' cannot be narrowly interpreted as 'the same register'. The stratified mode of context (as genre and register) introduced in Section 1 was in part conceived to cope with this issue (Martin, 1999a, 1999b, 2001, 2014). The model allows for changes in field, and/or tenor and/or mode, as afforded by the genre. Unstratified models of context do not have this flexibility, and so need to find alternative strategies for dealing with the dynamics of discourse (Hasan, 1980, Taverniers, 2021). As far as our stratified model of context is concerned we might re-phrase 'consistent in register' as 'consistent in genre', ${ }^{8}$ allowing for register variation at the stratum below.

For pedagogic discourse our model of context has to be expanded once more - to allow for the projection of a disciplinary field by an educational one (as outlined by Rose in Figure 7 above). What Rose's imaging does not make clear is that it is in fact a curriculum genre (realised by pedagogic activities, pedagogic relations and pedagogic modalities) that is projecting a second field. This understanding is incorporated into the '4D' SFL model of pedagogic discourse outlined in Figure 9. Therein Educational Discourse (ED) is understood as referring to one of the curriculum genres that have evolved or been designed to teach and learn; and like all genres these genres involve a field (in this case the pedagogic activity through which the teaching/learning unfolds). In a model of this kind shifts in field (or ultimately tenor or mode) can be explored as serving the telos of the relevant curriculum genre (+ED) or not (-ED). There is nothing locking teacher/learners into dedicated discourse. 
This discussion of register variation within a coherent text also has implications for pedagogy - and for our evaluation of different modes of teaching/learning in particular. The rise of Web 2.0 powered technologies and the effect of a recent global pandemic on their uptake has raised questions about the role of lecturing in education, especially in universities. But lecturing is a mode of teaching/learning that has evolved across sectors of education, for the very reason that it is a highly efficient mode of knowledge building that mediates between face-to-face exchanges of meanings and the written documents (print or electronic, monomodal or multimodal) where knowledge is stored for future generations. Arguing that lectures are passé depends on what Maton (e.g. 2014, Maton, Hood \& Shay, 2016) calls 'knowledge blindness' - in SFL terms he is referring to ignoring the meanings through which knowledge is made. Each and every mode is only as effective as the meanings it affords. And this is just as true for electronic modalities of communication as for the spoken and much later on print modalities which evolved long before Web 2.0.

This has important implications for secondary school education, as students are introduced to the specialised uncommon sense discourse of the sciences, social science and humanities and prepared for tertiary studies where the density and scope of the knowledge being reproduced lends itself to lecturing mode as an essential dimension of teaching/learning. Currently, in Australia, we have a situation where too often the students in privileged secondary schools are inducted into lecture mode as part of their apprenticeship - at the same time as students in less privileged schools are kept busy with hands-on activity promoted as fostering 'real' learning. This cripples students who have not learned to ingest knowledge from extended phases of uninterrupted spoken discourse, as preparation for the extended silent reading that has to be undertaken if they are to harvest the specialised knowledge in the multimodal texts where it is stored. Mastering a complementarity of modes is the key to success in education. We need to be very cautious about using technological innovation and financial austerity as an excuse to undermine a mode that has played such a critical role in education for so long - ignoring the meanings it affords as we do so.

\section{REFERENCES}

Bernstein, B. (1996). The structuring of pedagogic discourse. (Class, codes and control Volume IV). London: Routledge

Chiang, T. (1998). Story of your life. New York: Tor Books.

Christie, F. (2002). Classroom discourse: A functional perspective. London: Continuum.

Christie, F. \& Martin, J. R. (2007). Language, knowledge and pedagogy: Functional linguistic and sociological perspectives. London: Continuum.

Christie, F. \& Maton, K. (2011). Disciplinarity: Functional linguistics and sociological perspectives. London: Continuum. 
Doran, Y. J. \& Martin, J. R. (2021). Field relations: Understanding scientific explanation. In K. Maton, J. R. Martin \& Y. J. Doran (Eds.), Teaching Science: Knowledge, Language, Pedagogy (pp. 105-133). London: Routledge.

Halliday, M.A.K. (1985). An introduction to functional grammar. London: Arnold.

Halliday, M.A.K. (1991). Towards probabilistic interpretations. In E. Ventola (Ed.), Functional and systemic linguistics: Approaches and uses (pp. 39-61). Berlin: de Gruyter.

Halliday, M.A.K. (1992). How do you mean? In M. Davies \& L. Ravelli (Eds.), Advances in systemic linguistics: Recent theory and practice (pp. 20-35). London: Pinter.

Halliday, M.A.K. \& Greaves, W. S. (2008). Intonation in the grammar of English. London: Equinox.

Halliday, M. \& Hasan, R. (1976). Cohesion in English. London: Longman.

Hao, J. (2020). Analysing scientific discourse from a systemic functional linguistic perspective: A framework for exploring knowledge building in biology. New York: Routledge.

Hasan, R. (1980). What's going on?: A dynamic view of context in language. In J. E. Copeland \& P.W. Davis (Eds.), The seventh LACUS forum (pp. 37-50). Columbia: Hornbeam Press.

Hood, S. (2020). Live lectures: The significance of presence in the building of disciplinary knowledge. In J. R. Martin, K. Maton \& Y. J Doran (Eds.), Accessing Academic Discourse: Systemic Functional Linguistics and Legitimation Code Theory (pp. 211-235). London: Routledge.

Hood, S. \& Lander, J. (2016). Technologies, modes and pedagogic potential in live versus online lectures. International Journal of Language Studies, 10(3), 23-42.

Hood, S. \& Maggiora, P. (2016). A lecturer at work: Language, the body and space in the structuring of disciplinary knowledge in law. In H. de Silva Joyce (Ed.), Language at work in social contexts: Analysing language use in work, educational, medical and museum contexts (pp. 108-128). Newcastle upon Tyne: Cambridge Scholars.

Hood, S. \& Zhang, D. (2020). Graduation in play with other systems of meaning in the enactment of interpersonal relations'. Journal of Foreign Languages, 43(6), 21-41.

Humphrey, S., Hao, J. \& Rose, D. (2020). Launching research: A Martinian perspective on science pedagogy. In M. Zappavigna \& S. Dreyfus (Eds.), Discourses of hope and reconciliation: On J.R. Martin's contribution to Systemic Functional Linguistics (pp. 85-108). London: Equinox.

Lemke, J. L. (1995). Textual politics: Discourse and social dynamics. London: Taylor \& Francis. 
Martin, J. R. (1992). English text: System and structure. Amsterdam: John Benjamins.

Martin, J. R. (1999a). Mentoring semogenesis: 'Genre-based' literacy pedagogy. In F. Christie (Ed.), Pedagogy and the shaping of consciousness: Linguistic and social processes (pp. 123-155). London: Cassell (Open Linguistics Series).

Martin, J. R. (1999b). Modelling context: A crooked path of progress in contextual linguistics (Sydney SFL). In M. Ghadessy (Ed.), Text and context in functional linguistics (pp. 25-61). Amsterdam: John Benjamins (CILT Series IV).

Martin, J. R. (2001). A context for genre: Modelling social processes in functional linguistics. In J. Devilliers \& R. Stainton (Eds.), Communication in linguistics: Papers in honour of Michael Gregory (pp. 287-328). Toronto: GREF (Theoria Series 10).

Martin, J. R. (2002). From little things big things grow: Ecogenesis in school geography. In R. Coe, L. Lingard \& T. Teslenko (Eds.), The rhetoric and ideology of genre: Strategies for stability and change (pp. 243-271). Cresskill, N.J.: Hampton Press.

Martin, J. R. (2011). Bridging troubled waters: Interdisciplinarity and what makes it stick. In F. Christie \& K. Maton (Eds.), Disciplinarity: Functional linguistic and sociological perspectives (pp. 35-61). London: Continuum.

Martin, J. R. (2012). Making history: Grammar for interpretation. In J. R. Martin \& R. Wodak (Eds.), Re/ reading the past: Critical and functional perspectives on time and value (pp. 19-57). Amsterdam: John Benjamins.

Martin, J. R. (2013). Embedded literacy: Knowledge as meaning. Linguistics and Education, 24(1), 23-37.

Martin, J. R. (2014). Evolving Systemic Functional Linguistics: Beyond the clause. Functional Linguistics, 1, 3.

Martin, J. R. (2016). Meaning matters: A short history of systemic functional linguistics. Word, 61(2), 35-58.

Martin, J. R. (2020a). Genre and activity: A potential site for dialogue between Systemic Functional Linguistics (SFL) and Cultural Historical Activity Theory (CHAT) Mind Culture Activity, 27(3), 216-232.

Martin, J. R. (2020b). Metaphors we feel by: Stratal tension. Journal of World Languages, 6 $(1-2), 8-26$.

Martin, J. R. (2020c). Ideational semiosis: Field, discourse semantics, lexicogrammar. DELTA - Documentação de Estudos em Linguistica Teorica e Aplicada, 36(4), 1-27.

Martin, J. R. \& Rose, D. (2007). Working with discourse: Meaning beyond the clause. London: Continuum. 
Martin, J. R. \& Rose, D. (2008). Genre relations: Mapping culture. London: Continuum.

Martin, J. R. \&. White, P.R.R. (2005). The language of evaluation: Appraisal in English. London: Palgrave.

Martin, J. R., Wang, P. \& Zhu, Y. (2013). Systemic functional grammar: A next step into the theory-axial relations. Beijing: Higher Education Press.

Martin, J. R., Maton, K. \& Doran, Y. J. (Eds.) (2020a). Accessing Academic Discourse: Systemic Functional Linguistics and Legitimation Code Theory. London: Routledge.

Martin, J. R., Maton, K. \& Doran, Y. J. (2020b). Academic discourse: An interdisciplinary dialogue. In J. R. Martin, K. Maton \& Y. J. Doran (Eds.), Accessing Academic Discourse: Systemic Functional Linguistics and Legitimation Code Theory (pp. 1-31). London: Routledge.

Maton, K. (2014). Knowledge and knowers: Towards a realist sociology of education. London: Routledge.

Maton, K. \& Howard, S. (2018). Taking autonomy tours: A key to integrative knowledge-building. LCT Centre Occasional. Paper 1, 1-35.

Maton, K. \& Howard, S. K. (2021). Targeting science: Successfully integrating mathematics into science teaching. In K. Maton, J. R. Martin \& Y. J. Doran (Eds.), Teaching science: knowledge, language, pedagogy (pp. $\mathrm{xx}-\mathrm{xx}$ ). London: Routledge.

Maton, K., S. Hood, S. \& Shay, S. (Eds.) (2016). Knowledge-building: Educational studies in Legitimation Code Theory. London: Routledge.

Maton, K., Martin J. R. \& Doran, Y. J. (Eds.) (2021). Teaching science: Language, knowledge and pedagogy. London: Routledge.

Rose, D. (2018). Pedagogic register analysis: Mapping choices in teaching and learning. Functional Linguistics, 5(3), 1-33.

Rose, D. (2020). Building a pedagogic metalanguage I: Curriculum genres. In J. R. Martin, K. Maton \& Y. J. Doran (Eds.), Accessing Academic Discourse: Systemic Functional Linguistics and Legitimation Code Theory (pp. 236-267). London: Routledge.

Rose, D. \& Martin, J. R. (2012). Learning to write, reading to learn: Genre, knowledge and pedagogy in the Sydney School. London: Equinox.

Szenes, E. (2021). The language of business reasoning: Analysing student writing in higher education. In D. Caldwell, J. R. Martin \& J. Knox (Eds.), Bloomsbury Studies in Systemic Functional Linguistics (pp. xx- xx). London: Bloomsbury. 
Taverniers, M. (2019). Semantics. In G. Thompson, W. L. Bowcher, L. Fontaine \& D. Schöntal (Eds.), The Cambridge Handbook of Systemic Functional Linguistics (pp. 5591). Cambridge: Cambridge University Press.

Taverniers, M. (2021). Modelling interfaces with context in SFL: Stratification, instantiation, metafunctions. Functions of Language. DOI: https://doi.org/10.1075/fol.20015.tav

\section{NOTES}

${ }^{1}$ I am indebted to Maton and Rose for challenging feedback, only some of which has been accommodated in this paper; its current formulation is of course my responsibility alone.

2 There is an interesting contrast arising here with respect to Maton and Howard's (2018) treatment of the field of pedagogic activity as realising an introjected code (not a sovereign code) in relation to the target they establish for that analysis. There is of course nothing in LCT's model to prevent an analyst from treating both pedagogic activity and the disciplinary field it projects as sovereign - a decision having to do with one's descriptive focus, not LCT's autonomy theory.

${ }^{3}$ The contrast with science, social science and humanities discourse in general is striking - since in these discourses reasoning inside clauses is strongly favoured over reasoning between clauses or clause complexes (Martin, 2012, 2020c).

${ }^{4}$ Following SFL notation non-ranking embedded clauses are enclosed in double square brackets.

${ }^{5} \mathrm{In} \mathrm{SFL}$ a ranking clause is a clause that is not embedded.

${ }^{6}$ In Table 2 and Table 3 Minimal New is treated as the final experiential constituent of a clause (assuming unmarked TONALITY and TONICITY); see Martin and Rose (2007) for discussion.

${ }^{7}$ I have adopted a liberal interpretation of interpersonal Theme for this comment column, including three projecting clauses whose function is to enact the lecturer's stance towards their projections.

${ }^{8}$ For discussion of how genres combine in longer texts see Martin (2002) on genre complexing and Szenes (2021) on embedded genres; Martin's paper also critiques the once popular notion of a 'mixed genre'. 